\title{
An Audit of Municipal Solid Waste Management System in Selected Wards of Varanasi - A Case Study
}

\author{
Sourabh Manuja \\ Fellow, Environment and Waste Management Division, \\ The Energy and Resources Institute (TERI), \\ Indian Habitat Centre, Lodhi Road, New Delhi, \\ India-110003
}

Jai Kumar Gaurav

Technical Advisor, Deutsche Gesellschaft für Internationale Zusammenarbeit (GIZ) GmbH, GIZ India, New Delhi, India-110029

Suneel Pandey

Director, Environment and Waste Management

Division,The Energy and Resources Institute (TERI)

India Indian Habitat Centre, Lodhi Road,

New Delhi, India-110003

\author{
Nirbhay Kumar Singh \\ Project Consultant, \\ Environment and Waste Management Division, \\ The Energy and Resources Institute (TERI) \\ Vaibhav Rathi \\ Technical Advisor, Deutsche Gesellschaft für \\ Internationale Zusammenarbeit (GIZ) GmbH, \\ GIZ India, New Delhi, India-110029
}

\section{Kuldeep Choudhary \\ Project Consultant, Environment and Waste Management Division, \\ The Energy and Resources Institute (TERI)}

\begin{abstract}
Growing population, increasing urbanization and changing lifestyles impact the municipal solid waste (MSW) generation quantities, stressing the management infrastructure and cities ability to manage waste. To understand the existing MSW management scenario, level of implementation of waste management Rules, 2016 and citizen's engagement, an audit of MSW management system was conducted in the area of Varanasi Municipal Corporation (VMC) between $23^{\text {rd }}$ September 2019 to $01^{\text {st }}$ February 2020.

Audit covering 4754 citizens, spanning over 08 municipal wards found that almost every three of five residents find segregation confusing and only $24 \%$ residents' segregate waste. About $89 \%$ population had never received any Information Education and Capacity building (IEC) on source segregation. Further, Door to door collection services were provided by VMC to only $45 \%$ of the residents, and informal collectors covered around $6 \%$ so the total coverage was around $51 \%$, attributed to low willingness to pay user fee by residents as well as gap in infrastructure arrangement by VMC.

Percentage of population practicing home composting, wrapping and disposing sanitary waste was also determined through the audit to understand implementation of regulations. Fate of recyclables, domestic hazardous waste, status of user charges, appropriateness of waste collection services and waste management infrastructure were also evaluated as a component of this audit.

Audit also identified that $46 \%$ of population could still see carry bags of $<50$ micron thickness, banned as per regulations and VMC did not had any separate mechanism for collection, storage, transportation, processing and disposal of plastic waste, required as per the regulation.
\end{abstract}

This paper provides an insight to the audit findings and provides recommendations for VMC to improve their waste management services. Such study also provides a blueprint for other urban local bodies to help them assess the status of MSW management and take necessary corrective actions. The findings are particularly relevant for cities in the developing world, which is projected to have $97 \%$ of the population growth between 2013 and 2030 .

Keywords: Municipal Solid Waste, Source Segregation, Waste Collection, Waste Audit, Solid Waste Management Rules 2016,

\section{INTRODUCTION}

Over the past few years, growing population, rapid urbanization and changing lifestyles of people has made Municipal Solid Waste (MSW) management a challenge in most of the countries around the globe [1] [2] [3]. Presently, the world generates around 2.01 billion tonnes of MSW every year with about 7.7 billion population, as population is expected to rise by about $10 \%$ till 2030 , waste generation quantities are also expected to reach 2.58 billion tonnes a year [4] [5]. Moreover, estimates reveal, till date almost a third of global waste isn't managed in an environmentally safe manner in current situation [6] and solid waste disposal alone is responsible for $5 \%$ of total Greenhouse gas emissions [7]. It is also anticipated that $97 \%$ of the population growth from 2013 to 2030 will be in developing countries and urbanization levels will rise to $56 \%$ [8] [9], making the situation more challenging here. 
Indian urban areas which account for around 34\% [10] of the total 1.37 billion population of India [4], generate around 58.87 million tonnes of MSW every year, of this total generated MSW only $86 \%$ could be collected and only $27 \%$ of the collected was treated [11] [12] [13]. Although, Solid Waste Management Rules, 2016 clearly directed cities to divert all of the organic waste from landfills and create material recovery facilities (MRF) to manage dry waste with the target of creating zero landfill cities the progress has been limited. It is estimated that urbanization level in India will rapidly increase to about $40 \%$ by 2030 [14] , and MSW quantities will reach around 165 million tonnes a year [15], reflecting an urgent need for Indian cities to manage the presently unmanaged MSW quantities.

Inappropriate management of waste, as well as disposal of valuable organic waste at unscientific disposal sites, create another level of challenges: both at health and environmental front [16]. U. S. Public health Service identified 22 types of diseases associated with improper solid waste management [17]. The Energy and Resources Institute study estimated 13.75 million tonnes $\mathrm{CO}_{2}$ eq $\mathrm{GHG}$ emissions from Indian solid waste sector in year 2011, which are expected to rise at a Compounded annual growth rate of $2.55 \%$ till 2031, indicating linkage with climate change. [18]. These studies highlight the need for identifying lacunas and formulating appropriate strategies to manage MSW in urban clusters. This is also important to help meet the Nationally Determined Contributions (NDCs) commitments made by Government of India as part of the Paris Agreement to reduce GHG emission intensity of its GDP by 33-35\% by 2030 from 2005 levels [19].

In year 2014, Swachh Bharat Mission was adopted which targeted providing services to $80 \%$ of the urban population by 2019 , allowing for a $2 \%$ increase year on year [20]. Thereafter, in 2016 Solid Waste Management Rules were enacted, which emphasized, segregation at source and segregated waste collection from every household, indicating a clear engagement with urban citizens in managing waste, starting from segregation. The Rule also emphasized for door to door collection, segregated transportation, processing and thereafter disposal of only rejects. [21].

As a first step to any problem solving, we need to identify the problem, set objective and demarcate associated challenges. This helps establishing a baseline, for planning future tasks and targets. MSW management audits of urban local bodies help in identifying the level of services, compliance to existing policies and regulations and level of public participation, thereafter helping cities improve their MSW management practices. The same strategy was implemented in one of the oldest cities in the world, Varanasi to help improve level of MSW management services and help divert MSW from going to landfill. MSW audits were conducted by interviewing households through targeted questions ranging from waste segregation, Inhouse treatment, waste collection services, fate of recyclables, management of domestic hazardous waste and plastic waste.

This paper provides insights on MSW management in Varanasi based on the primary surveys which were conducted across selected wards of Varanasi and provides details of the methodology adopted. This audit provides information about the waste management practices, MSW management related awareness levels among the citizens of Varanasi, outlines the gaps, associated challenges and recommendations for improvising the services. This paper will be useful for all the cities interested in improving their MSW management practices, and engaging citizens in reducing, reusing, recycling and recovery of waste, turning waste to wealth. This will also be helpful for monitoring agencies and cities to record compliance with respect to solid waste management rules 2016 and plastic waste management rules 2016.

\section{METHOD AND METHODOLOGY}

Varanasi is one of the oldest cities of the world, situated at the bank of holy river Ganges in the North Indian state of Uttar Pradesh with Latitude $25^{\circ} 19^{\prime} 18.0624^{\prime \prime} \mathrm{N}$ and Longitude $82^{\circ}$ 59' 14.2404" E. Varanasi Municipal Corporation area has 90 wards and land area of $82.10 \mathrm{Sq}$. Kms [22]. Varanasi city has had a resident population of around 14,41,251 in 2018 and due to its rich tourism potential, the daily estimated flow of tourists to the city was estimated around 25,000 [23]. Varanasi city is estimated to generate around 749 tonnes per day (TPD) of MSW and collect around 75.7 percent of this generated MSW [24]. The city also estimates to generate around 1,31,547 tonnes $\mathrm{CO}_{2} \mathrm{Eq} \mathrm{GHG}$ emissions from solid waste management [25]. According to the Varanasi Solid Waste ManagementAction Plan, it is estimated that by 2031 MSW generation will increase to about 889.74TPD [22].

A waste characterization study in Varanasi revealed that solid waste collected from wards constituted around $29.2 \%$ organic waste, $5.4 \%$ paper, $4.8 \%$ plastic, $0.3 \%$ metal, $0.2 \%$ glass, $7 \%$ leather and textile, $2.1 \%$ sanitary waste, $7.7 \% \mathrm{C} \& \mathrm{D}$ waste, $0.6 \%$ domestic hazardous waste , $0.7 \%$ tires, $0.1 \%$ electronics and $40.5 \%$ fines [26]. Depicting a lot of valuable resource, which is easily recyclable and recoverable, being diverted to disposal facilities.

The city also has 03 bio-methanation plants to handle total 15 TPD organic waste, producing electricity from the generated biogas. Varanasi's dumpsite which is situated at Karsada also has a 600 TPD capacity windrow composting facility, to manage organic waste. Current situation reveals that all the bio-methanation plants were operating way below capacity and compost produced at Karsada facility did not had a good market, due to its quality. The reason behind this low quantity and quality outputs have been non-segregation of MSW at source, making it difficult for plants to get the correct quality feed.

The Material Recovery Facilities (MRFs) operated at Bhelupur and Lallapura wards are also not operating at their determined capacity as MSW collected is mixed, requiring excessive energy inputs to segregate, making recovery unfeasible. Also, mixed waste handling causes soiling of paper and plastic wraps leading to difficulties in recycling while if the MSW was segregated in dry and wet fraction these would have been easily recyclable.

Thus, to assess the implementation of MSW management rules in Varanasi, availability of infrastructure and awareness among citizens an audit was designed. The audit questionnaire as depicted in annexure 1 consisted of questions targeting segregation practices at household, reasons for nonsegregation, fate of recyclable and organic waste generated, status of appropriate door to door collection, frequency and 
appropriateness of waste collection system, cleanliness and availability of twin bin systems, and management practices for sanitary and domestic hazardous waste. The survey also collected information about information, education and capacity building (IEC) activities among citizens on segregation and composting, effectiveness of such IECs, user fee for waste management and complain redressed mechanisms. Implementation of Plastic Waste Management Rules 2016 were also assessed through the audit questions.

Due to limitation of time and resources, the audit was targeted on residents and covered 08 wards spread in 2 zones of total 05 zones from $23^{\text {rd }}$ September 2019 to $01^{\text {st }}$ February 2020, involving primary surveys with 4754 residents. The list of 08 wards and respective stakeholders have been shown in table 1 .

TABLE 1: LIST OF WARDS AND STAKEHOLDERS REACHED DURING THE MSW MANAGEMENT AUDIT

\begin{tabular}{|c|c|c|c|}
\hline Ward name & Zone name & $\begin{array}{l}\text { Stakeholders } \\
\text { reached }\end{array}$ & $\begin{array}{l}\text { Cumulative } \\
\text { stakeholders } \\
\text { reached }\end{array}$ \\
\hline Sunderpur & \multirow{3}{*}{ Dashaswamedh } & 336 & 336 \\
\hline $\begin{array}{l}\text { Lallapura } \\
\text { Khurd }\end{array}$ & & 660 & 996 \\
\hline Gandhi Nagar & & 498 & 1494 \\
\hline $\begin{array}{l}\text { Kazipura } \\
\text { Khurd }\end{array}$ & \multirow{5}{*}{ Bhelupur } & 480 & 1974 \\
\hline Khojwa & & 540 & 2514 \\
\hline Bhelupur & & 672 & 3186 \\
\hline Sudamapur & & 980 & 4166 \\
\hline Birdopur & & 588 & 4754 \\
\hline
\end{tabular}

This study was targeted to help the urban local bodies in formulating necessary plan and actions for improving their service level of MSW management and make Varanasi city waste management more effective and sustainable.

\section{RESULTS \& DISCUSSIONS}

The audit results indicate that only $24 \%$ of the respondents were segregating their waste at source, with $90 \%$ of these segregating it into two streams organic and inorganic, and $3 \%$

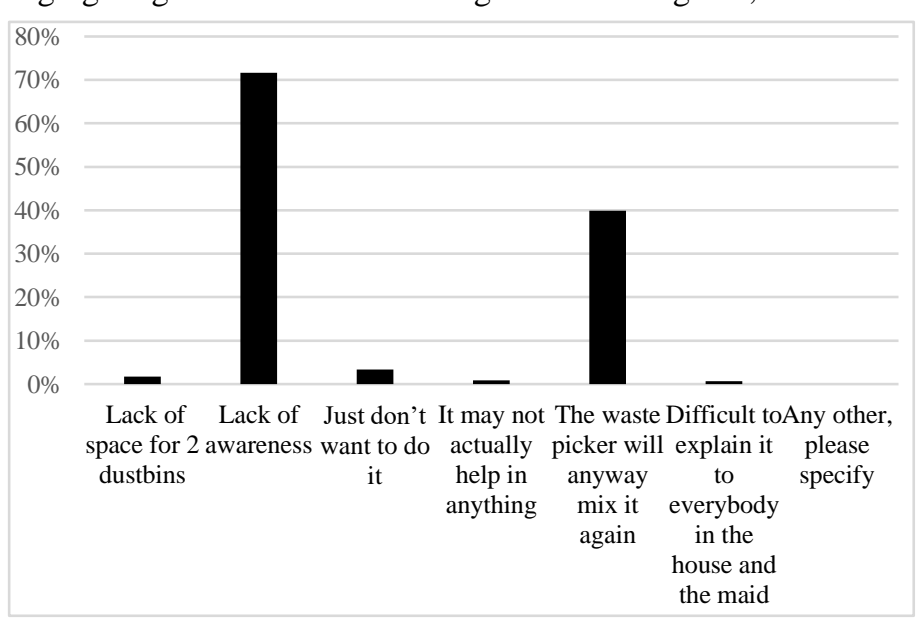

Fig. 1 Response to reasons for non-segregation of waste of these segregating into three streams, including household hazardous waste. Remaining 7\% of these respondents only partially segregated their organic waste for feeding it to animals. About $62 \%$ respondents were of the opinion that segregation is confusing, they did not had a clear idea of what goes where, and how do we segregate effectively. Respondents were asked reasons for not segregating waste, they had multiple answers, which are depicted in figure 1.

On the fate of recyclable waste generated, respondents had multiple answer, as the response varied depending on situation. About $78 \%$ reported disposing it with on many instances MSW, $87 \%$ indicated handing over to informal sector as and when available, $2 \%$ reported of disposing them in nearby Dhalao, and $1 \%$ were handing over to authorised recycler, remaining $1 \%$ also reported of reusing the recyclables like paper to make bags.

When asked on the fate of organic waste generated from households, multiple answers were received as depending on the situation their disposal route varied. About $1.7 \%$ of the respondents were composting organic waste and $81.3 \%$ of them were feeding their organic waste to animals (consisting of leftover fruits, vegetables), $0.1 \%$ of respondents were throwing this in drains and $0.5 \%$ were disposing organic inappropriately at garbage vulnerable points, $84.8 \%$ also were handing over (mostly perishable/rotten left over) organic waste with MSW.

The audit also tried to capture the status of IECs among stakeholders on organic waste management and waste segregation and indicated that only $18 \%$ and $11 \%$ respectively had had received IECs. In terms of effectiveness of these IECs for clarity in objective, only about 52 percent agreed that these were effective.

On the infrastructure side, surprisingly only $4 \%$ respondents conceded that Urban Local Body collects segregated waste from households. Stakeholders also revealed that VMC was providing door to door collection services to about $45 \%$ of the households in surveyed area and $6 \%$ of the services were through informal waste collectors, privately operating. Figure 3 clearly depicts the split on waste collection services, reflecting a clear need to enhance the service levels.

When asked on the fate of collected MSW, about $60.32 \%$

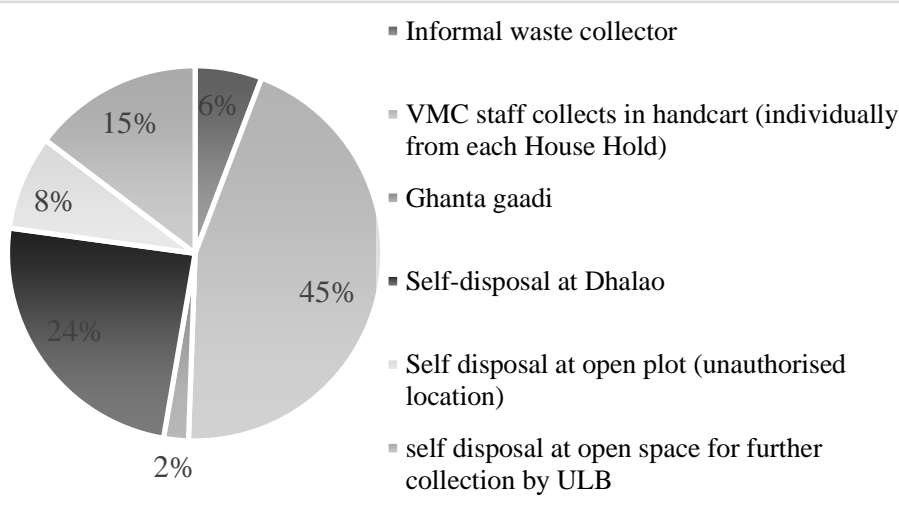

Fig. 2 Waste collection mechanism from households

of the respondents has had no idea, $18.27 \%$ agreed that it is collected at Dhalao without any recovery and $13.27 \%$ were of the opinion that it is disposed at Dhalao after recovery. About 
$3.55 \%$ respondents were also of the opinion that waste is disposed on open plots after recovery of recyclables and $4.07 \%$ were of opinion for disposing waste at plots without recovery of recyclables.

Audit survey also revealed that of the households generating sanitary waste, only $38 \%$ were following SWM Rules 2016 and wrapping the waste separately for disposal with dry waste. Domestic hazardous waste (DHW) like acid bottles, spray cans, toilet cleaner bottles, dry cell batteries etc. were segregated by only $21 \%$, and further $98 \%$ agreed that waste collector does not collect DHW separately. There was no DHW collection center reported in nearby localities and majorly, 99\% of generated DHW was disposed with MSW only. Clearly indicating a huge gap in DHW management.

It is well known that users only like to pay for services that they see directly impacting them, for indirect services like waste transportation, treatment and disposal users are not willing to pay. In Varanasi audits revealed that only $20 \%$ of the respondents were paying user charges for waste collection that too ranging from INR 30 to INR 150 per month, depending on the members of family and floor on which they stay.

About $76 \%$ of the respondents were getting waste collected once per day, whereas $20 \%$ reported of waste being collected on alternate days. When asked, if the collection frequency was adequate, $27 \%$ of the respondents denied. Mostly, $72 \%$ were getting waste collected before 9:00 am and 27\% between 9:00 am to $12: 00 \mathrm{pm}$, for which $31 \%$ said the time of waste collection was not suitable.

One third of the respondents agreed to see municipal bins in and around public places in Varanasi but of the total respondents, only $24 \%$ agreed to have twin bin system.

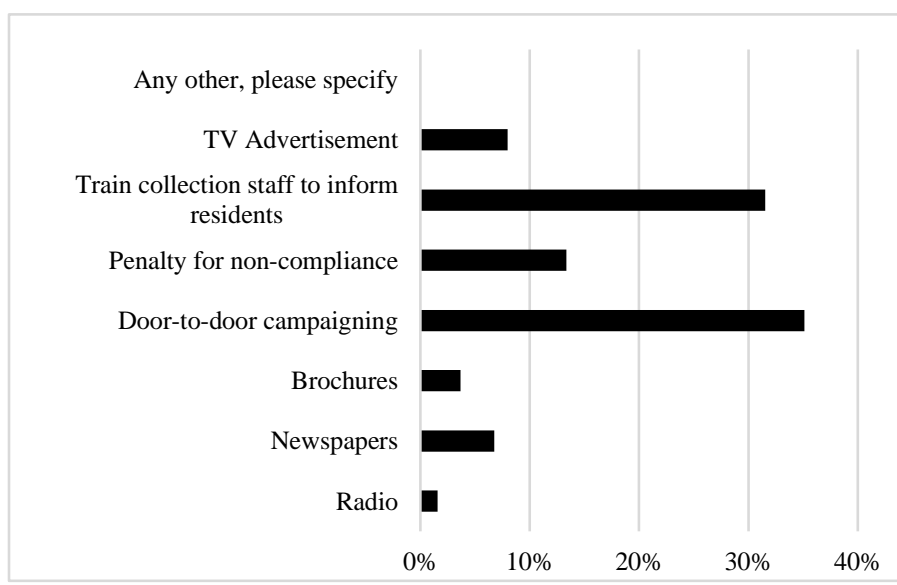

Fig. 3. Effective methods of awareness generation reported by stakeholders

Further, $89 \%$ were not identifying the waste collection spots or bins clean. Since, this was a perception-based response during audit, it indicated lack of infrastructure and upkeep in Varanasi.

Residents of Varanasi also reflected that door to door campaigning and trainings via waste collection staff, are effective methods of awareness generation, be it on waste segregation, composting etc. Figure 4 reflects the multiple choices reflected by respondents.

It was also learned that in about $55 \%$ of the cases the collector does not have an appropriate notification mechanism (whistle / horn) to indicate his arrival. And, 93\% residents are not even aware about any complain booking mechanism with their ULB.

About $69 \%$ reported of street cleaning being done regularly, but only $54 \%$ respondents reported that they find the streets clean. Clearly indicating a need to deploy better monitoring mechanisms among the ground level staff, in terms of quality and quantity of their allocated tasks.

As per Plastic waste management (PWM) rules of 2016, amended in 2018 ULBs have to ban usage of <50micron thick plastic bags, and recycled plastic or product of recycled plastic use for storing, carrying, dispersing or packaging ready to eat or drink stuff [27]. About $46 \%$ respondents agreed to still see usage of carry bags with $<50$ Micron thickness and $28 \%$ also agreed that recycled plastic products are used for storing, carrying, dispersing or packaging ready to eat or drink stuff. PWM Rules 2016 (under section 6.1) also require ULBs to make appropriate separate mechanism for collection, storage, transportation, processing and disposal of plastic waste. No such mechanism was reported by any of the respondent in Varanasi. Indicating lacuna's in PWM rules implementation. VMC officials claimed that in recent past months, two Material Recovery Facilities (MRFs) have been installed in Varanasi that are managing plastic waste. This study however outlined that a significant increase in number of MRFs will be required to meet the requirements of SWM Rules, 2016 and PWM Rules, 2016.

\section{CONCLUSION}

This data gathered during the study reveals that although there is significant potential for making MSW management in Varanasi more effective and efficient, with decentralized approaches and citizen's participation, there are certain grey areas which have to be taken care of.

Lower level of segregation at source and confusions over segregation among citizens indicate a need for higher level of engagement into these issue by VMC through door to door campaigns and on ground staff. Systems for segregated waste collection and appropriate door to door collection mechanisms are also needed, with a policy in place which allows user fee collection and citizen participation. VMC in its jurisdiction should come up with more aggressive decentralized waste management solution like MRFs for dry waste and plastic waste management in particular. Decentralized composting and bio-methanation should also be promoted.

Based on the findings of the audit, few recommendations on various functional elements were drawn for Varanasi city and have been shown in table 2. However, it is utmost important that proper monitoring, review and verification systems are in place before implementing strategies and such mechanisms are rigorously followed. 
TABLE 2: IDENTIFIED CHALLENGES AND OPPORTUNITIES FOR ENHANCING WASTE MANAGEMENT SERVICES IN VARANASI

Functional

element of waste

management

Challenges/Gaps

Opportunities

for

\begin{tabular}{l|l} 
Waste Generation & $\begin{array}{l}\text { Lack } \\
\text { source }\end{array}$ \\
segregai
\end{tabular} segregation

of - Capacity building with actions suggested for VMC identified

(a)

\section{campaigns.}

- Implementing systems for segregated collection of MSW.Establishing a system with appropriate monitoring mechanism with appreciation for compliance and penalties for non-compliance.

- Recognition and promotion of authorised plastic waste collections, linked with MRF facilities.

Improper organic $\quad \cdot \quad$ Promoting homewaste composting methods, \begin{tabular}{l|l} 
management providing composters via &
\end{tabular} enlisted manufacturers.

- Linking segregated organic waste with decentralized biomethanation plants and centralised composting facility.

Lack of - Awareness program about awareness about domestic hazardous waste domestic through door to door hazardous waste campaigns and ULB staff is and its required.

management

Lack of user fee $\quad$ After streamlining collection

Waste Collection

Door to door collection is very less

appropriate infrastructure and mechanism, citizen participation should be made mandatory. There should be mechanism to penalize nonusage of service and nonpayment of user charges.

- Assurance of regular service by ULB and user charges for service, will link more households to the chain.

- Infrastructure to handle segregated waste at primary and secondary collection level, training of collectors and penalization for noncompliance will also be required.

Lack of system - Capacity building with for handling proper training among the domestic household waste collector- on segregated waste collection

hazardous waste - Appropriate collection, storage and linkage with Treatment Storage and Disposal Facility (TSDF).

$\begin{array}{llll}\text { Segregated } & - & \text { A } & \text { separate }\end{array}$ plastic waste collection of plastic must be collection and initiated, engaging citizens, management collectors and MRF operators. Inadequate $\quad$ For markets and tourist availability of places, twin bin system must twin bin system at be enforced and cleaned \begin{tabular}{l|l} 
markets & regularly at a set frequency. It
\end{tabular} is equally important to

\begin{tabular}{|c|c|c|}
\hline $\begin{array}{l}\text { Functional } \\
\text { element of waste } \\
\text { management }\end{array}$ & $\begin{array}{l}\text { Challenges/Gaps } \\
\text { identified }\end{array}$ & $\begin{array}{lr}\text { Opportunities } & \text { for } \\
\text { improvement/ } & \text { corrective } \\
\text { actions suggested for VMC }\end{array}$ \\
\hline & & $\begin{array}{l}\text { establish monitoring } \\
\text { mechanisms and adequate } \\
\text { timings for bringing waste to } \\
\text { these points and lifting them. } \\
\text { - All households should be } \\
\text { linked with door to door } \\
\text { service and existing Dhalao } \\
\text { should be converted to MRF } \\
\text { centers. }\end{array}$ \\
\hline & $\begin{array}{l}\text { Lack of domestic } \\
\text { hazardous waste } \\
\text { collection center }\end{array}$ & $\begin{array}{l}\text { - With appropriate } \\
\text { planning and collection } \\
\text { mechanism, as per SWM rules } \\
2016 \text { every } 20 \mathrm{~km}^{2} \text { area should } \\
\text { have a domestic hazardous } \\
\text { waste collection center. This } \\
\text { should be liked via black } \\
\text { drum (for DHW) collection to } \\
\text { these points. }\end{array}$ \\
\hline & $\begin{array}{l}\text { Lack of feedback } \\
\text { /grievance system }\end{array}$ & $\begin{array}{l}\text { - Public feedback, makes } \\
\text { them more engaged with the } \\
\text { system, when they feel } \\
\text { services to certain } \\
\text { benchmarks are provided, } \\
\text { they participate to make } \\
\text { systems successful. } \\
\text { Appropriate helpline } \\
\text { numbers and feedback } \\
\text { systems should be set in place } \\
\text { and communicated to citizens, } \\
\text { regularly. }\end{array}$ \\
\hline \multirow[t]{2}{*}{ Treatment } & $\begin{array}{l}\text { Inappropriate } \\
\text { efficiencies of } \\
\text { existing organic } \\
\text { waste } \\
\text { management } \\
\text { facilities }\end{array}$ & $\begin{array}{l}\text { - With emphasis for in-house } \\
\text { treatment, decentralized } \\
\text { facilities should be linked } \\
\text { with bulk waste generators } \\
\text { and door to door collected } \\
\text { organic waste. } \\
\text { - More number of } \\
\text { decentralized facilities should } \\
\text { be established with } \\
\text { performance-based contracts. } \\
\text { - Centralized units should } \\
\text { have separate collection } \\
\text { vehicles, bringing organic } \\
\text { waste for processing. }\end{array}$ \\
\hline & 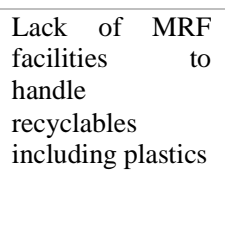 & $\begin{array}{l}\text { - Dhalaos should be converted } \\
\text { to MRFs and all collected dry } \\
\text { waste should be sold via } \\
\text { auctions. These MRFs should } \\
\text { be operated via existing waste } \\
\text { dealers in Varanasi, through } \\
\text { contracts. }\end{array}$ \\
\hline
\end{tabular}

In line with the findings of the audit, an action plan to target $100 \%$ segregation with citizen participation, door to door collection, segregated transportation and treatment can not only help implementing waste management rules more effectively, but can make Varanasi a zero-landfill city. Thus, not only reducing GHG emissions and increasing efficiencies of existing treatment plants, but also making the output products more valuable. This can turn the way waste is presently looked at Varanasi and turn it into a resource. 
This was a unique study conducted in City of Varanasi to help the ULB formulate necessary plans and actions for improving their service levels in MSW management domain. This study could have been more robust, including other stakeholders like bulk waste generators, markets, sanitary supervisors, waste collectors and transporters.

\section{ACKNOWLEDGMENT}

We acknowledge GIZ Grant to TERI on project Development and Management of NAMA in India via contract number 81230302 dated 02 October 2018, which helped us conduct this study at Varanasi. We also acknowledge the financing support from the Federal Ministry for the Environment, Nature Conservation, and Nuclear Safety (BMU) for the project "Development and Management of Nationally Appropriate Mitigation Actions (NAMAs) in India" with Ministry of Environment, Forest and Climate Change (MoEFCC), Government of India as lead executing agency. The Waste Management related activities in Varanasi were supported as part of the Waste NAMA pilot activity. We also acknowledge VMC for permitting us to audit their wards, and provide relevant information, without which this activity could have not been possible.

\section{REFERENCES}

[1] D. Vij, "Urbanization and Solid Waste Management in India: Present Practices and Future Challenges," Procedia - Social and Behavioral Sciences, vol. 37, pp. 437-447, 2012.

[2] S. Kumar, S. R. Smith, G. Fowler, C. Velis, S. J. Kumar, S. Arya, R. R. Kumar and C. Cheeseman, "Challenges and Opportunities associated with waste management in India," Royal Society Open Science, vol. 4, no. 3, pp. 1-11, 22 March 2017.

[3] E. Achankeng, "Globalization, Urbanization and Municipal Solid Waste Management in Africa," in African on a Global Stage, 2003.

[4] United Nation, "World Population Prospects," United Nation, New York, 2019.

[5] S. Kaza, L. Yao, P. Bhada-Tata and F. Van Woerden, What A Waste 2.0: A Global Snapshot of Solid Waste Management to 2050, Washington, Washington DC: World Bank, 2018.

[6] Climate \& Clean Air Coalition, https://ccacoalition.org/en/news-media, Paris: Climate \& Clean Air Coalition, 2020.

[7] J. Bogner, M. A. Ahmed, C. Diaz, A. Faaij, Q. Gao, S. Hashimoto, K. Mareckova, R. Pipatti and T. Zhang., "Waste Management, In Climate Change 2007: Mitigation. Contribution of Working Group III to the Fourth Assessment Report of the Intergovernmental Panel on Climate Change," Cambridge University Press, Cambridge, United Kingdom and New York, NY, USA., 2007.

[8] United Nations Population Fund, "Population Dynamics in the Least Developed countries: Challenges and opportunities for development and poverty reduction," UNPFA Technical Division, New York, USA, 2011.

[9] consultancy.uk, "News: $97 \%$ of population growth to be in developing world," 24 June $2015 . \quad$ [Online]. Available: https://www.consultancy.uk/news/2191/97-percent-of-population-growthto-be-in-developing-world. [Accessed 7 May 2020].
[10] World Bank, "https://data.worldbank.org/," World Bank, 2018. [Online]. Available:

https://data.worldbank.org/indicator/SP.URB.TOTL.IN.ZS ?locations=IN . [Accessed 4 May 2020].

[11] Central Pollution Control board, "Consolidated Annual Review Report on IMPLEMENTATION OF MUNICIPAL SOLID WASTES," Central Pollution Control board, New Delhi, 2015.

[12] Central Pollutiona Control Board, "Annual Report 2015-16," P. R. Division, CPCB, New Delhi, 2016.

[13] Cetral Pollution Control Board, "Consolidated Annual Review Report on Implementation of Solid Waste Management Rule, 2016," Cetral Pollution Control Board, New Delhi, 2017.

[14] McKinsey Global Institute, "India's urban awakening: Building inclusive cities, sustaining economic growth," McKinsey \& Company, 2010.

[15] R. Joshi and S. Ahmed, "Status and challenges of municipal solid waste management in India: A review," Cogent Environmental Science, vol. 2 , no. $1139434,2016$.

[16] Vikas, "Solid waste management in Indian cities: Issues and challenges," International Journal of Advanced Educational Research, vol. 2, no. 5, pp. 241-248, September 2017.

[17] World Bank, "WHATA WASTE:SOLID WASTE MANAGEMENT IN ASIA," World Bank, 1999.

[18] S. Manuja, A. Kumar and S. Pandey, "Greenhouse Gas Emissions and Reduction Stratagems from Waste Sector in India," International Journal of Latest Engineering Research and Applications, pp. 17-26, 2018.

[19] United Nation Framework Convention on Climate Change, 25 September $2015 . \quad$ [Online]. Available: https://www4.unfccc.int/sites/ndcstaging/PublishedDocuments/India\%20 First/INDIA\%20INDC\%20TO\%20UNFCCC.pdf. [Accessed 55 2020].

[20] Ministry of Housing and Urban Affairs, "Guidelines for Swachh Bharat Mission-Urban," Ministry of Housing and Urban Affairs, New delhi, 2017.

[21] Ministry of Forest and Climate Change, "Solid Waste Mangement Rule," Union Ministry of Forest and Climate Change, New Delhi, 2016.

[22] Varansi Municipal Corporation, "Solid Waste Management Plan," Varanasi Municipal Corporation, Varanasi, 2019.

[23] S. K. Tripathi, "Municipal solid waste management in Varanasi, India," International Journal of Technical Innovation in Modern Engineering \& Science (IJTIMES), 2018

[24] The Energy and Resources Institute, "As-Is Assessment report: Varanasi Development and Management of NAMA in India," The Energy and Resources Institute, New Delhi, 2019 a.

[25] The Energy and Resources Institute, "Short Lived Climate Pollutant Estimation from MSW sector- Baseline Emission for Varanasi and Panaji," TERI, New Delhi, 2019 b.

[26] The Energy and Resources Institute, "Municipal Solid Waste Characterisation study for Varanasi," The Energy and Resources Institute, New Delhi, 2019c.

[27] Ministry of Environment, Forest and Climate Change, "Home: Plastic Waste Management Rules," 18 March 2016. [Online]. Available: http://www.indiaenvironmentportal.org.in/content/426634/plastic-wastemanagement-rules-2016/. 